\title{
Impact of Agriculture on Bank Credits in Nigeria: An Econometric Analysis
}

\author{
Braimah Mathias and Momoh Abdulazeez Onoshole \\ Department of Humanities and Social Sciences, School of General Studies, Auchi Polytechnic Auchi \\ mathiasbrai@gmail.com, kasmoh4real@gmail.com
}

\begin{abstract}
In most developing countries, agriculture is both the main sector that provides employment to large segments of the population and the key to sustained economic growth of the countries like Nigeria. This study presents an empirical analysis of the Impact of Agriculture on Bank Credit in Nigeria.. Also, highlighted are the problems of agricultural production in Nigeria and the strategies for agricultural transformation of the economy. Our findings revealed that agricultural variables have impact on food industries in Nigeria. Consequently, the macroeconometric model in this study contributes to the development of policy and programming by shedding light on the choice to be made and indicating the magnitude and direction of responses that can be expected from changes in key agricultural policy. It is a known fact that the efficiency of credit facility positively contributes to production base of a sector, especially the Nigerian agricultural sector which is recognised as the heartbeat of the economy by employing over $70 \%$ of the country's labour force; this forms the motivation for this study. This study also deals with the potentials of agricultural output in terms of commercial bank loan to agriculture and agricultural credit scheme as well as their corresponding interest rates to farmers towards increasing agricultural production as the pathway to food industries in Nigeria. The study employed the Autoregressive Distribution Lag (ARDL) econometric approach on the time series data sourced from the Central Bank of Nigeria (CBN) statistical bulletin, Food and Agriculture Organisation (FAO) and the World Development Indicators (WDI) for the period 19982018. The result from ARDL showed that commercial banks loan and Agricultural Credit Scheme increased food industries and agricultural output by $8.12 \%$ and $0.002 \%$ respectively, while population reduces Agricultural Output by $0.001 \%$.
\end{abstract}

Keywords: Agriculture, Bank Credits, Nigeria

DOI: $10.7176 / \mathrm{JESD} / 12-12-13$

Publication date:June $30^{\text {th }} 2021$

\section{Introduction}

Nigeria is popularly known as the largest oil producing country in Africa. Agriculture remains the base of its economy. Nigeria's agricultural sector employs two-thirds of the country's labour force and accounts for about a quarter of the Gross Domestic Product (GDP). Small-scale women farmers contribute significantly to local food production and constitute over 60 per cent of the agricultural labour force. However, agriculture remains the base of the Nigerian economy providing the main source of livelihood for most Nigerians \{Sue and John (2015)\}. The sector faces many challenges, notably an outdated land tenure system that constrains access to land, a very low level of irrigation development, limited adoption of research findings and technologies, high cost of farm inputs, poor access to credit, inefficient fertilizer procurement and distribution, inadequate storage facilities and poor access to markets have all combined to keep agricultural productivity low with high post-harvest losses and waste (Marette, 2002).

Despite agriculture remains the largest sector of the Nigerian economy and employs two-thirds of the entire labour force, the production hurdles have significantly stifled the performance of the sector (Ronald, 2019). Over 20 years, value-added per capita in agriculture has risen by less than 1 percent annually. It is estimated that Nigeria has lost USD 10 billion in annual export opportunity from groundnut, palm oil, cocoa and cotton alone due to continuous decline in the production of those commodities. Food production increases has not kept pace with population growth, resulting in rising food imports and declining levels of national food self-sufficiency (FMARD, 2008). The main factors undermining production include reliance on rainfed agriculture, smallholder land holding, and low productivity due to poor planting material, low fertilizer application, and a weak agricultural extension system amongst others (Anna, 2012).

The food industry is a key sector of the economy that protects and supports the population, provides jobs, and generates the budgets of large and small areas. Food industry -meat, milk, fat, fish products, flour, bread, pasta, canned vegetables, confectionery, tea packaging, grape and champagne wine, alcohol, vodka, tobacco, beer, soft drinks, many industrial enterprises producing soap and other products. The agricultural sector in Nigeria remains a dominant economic force, contributing $25.2 \%$ (N10.50 trillion) to the nation's GDP as at 2019. While this might seem impressive, according to estimates Nigeria has also lost up to $\$ 10$ billion (ten billion United States 
Dollars) in annual export opportunities from groundnut, palm oil, cocoa and cotton alone, due to continuous decline in the production of those commodities3. Subsistence farming is insufficient to meet the challenges of the industry including rising cost of supplies, labour shortages, reduced productivity, changes in consumer preferences and so on.

Discussing the above with respect to national strategy, it is incumbent upon the federal government to facilitate the use of technology and innovation to increase agriculture as a means to speed up the economic recovery that it desperately needs post-COVID-19. The efficiency and effectiveness of credit facility contribute immensely to production base of a sector, especially the Nigerian agricultural sector which is considered as the backbone of the economy. The Nigerian agricultural sector employs more than one-third of the country's Gross Domestic Product (GDP), provides approximately $75 \%$ of the rural employment and contributes about $35 \%$ to poverty reduction. However, as argued by Malthus food production in developing countries has not been commensurate with the level of population growth; this is because the growth and competitiveness of the agricultural sector have been decreasing due to farmers' lack of credit facilities to attain the required level of production. Provision of credit facilities to farmers has been widely recognised as an effective policy for the enhancement of food production to cater for the teeming population, as used in the work of Obadan (2001).

Inaccessibility of credit facility by farmers affects farm production in the sense that farmers experiencing capital constraint may tend to use a lower level of farm inputs in the production process. On the other hand, sufficient access to credit facilitates by farmers improves input use on the farm and therefore have an import effect on agricultural productivity. Thus, access to credit facilities enables farmers to satisfy their cash desires encouraged by the agricultural production cycle and consumption requirements. For instance, it was noted that in Ghana, the incidence of food shortage in 2009 was fuelled by lack of agricultural credit facilities to farmers for the required level of food production. It is widely believed in literature that to a large extent, agricultural output is a function of an adequate food production as well as income to meet the households' nutritional level. Agricultural credit facility to farmers could be in form of funds available to farmers to enable them buy the required farm inputs like; fertilizer, quality seeds, herbicides and pesticides into agricultural activities, and also enables them buy capital equipment like hoes, cutlasses, and water pumps has long been known to be some of the main hindrance of efficient food productivity in smallholder agriculture and lack of equipment to control emissions of greenhouse gases which damages crops and animals and negatively affect farmers health status.

The increased global need for food is a problem for humanity \{Rahji and Fakayode (2009); Jacobsen et al., 2013)\}. Increasing food production to feed the teeming world population will continue to be a difficult task due to fewer arable land, high cost of farm implements needed for production as a result of inflation, less credit access to farmers, the land competition of food production with bio-fuel production and rural-urban migration among others (Jacobsen et al., 2013). As a result of this, there is a strong on-going deliberation on the best approach to gain speed with world population growth and increasing food production to meet the United Nations (UN) Sustainable Devolvement Goal 2 (which is to achieve food security at all level, improve nutrition for all, and promote sustainable agriculture) by 2030 (Osabohien et al., 2020; Osabohien et al., 2019). To improve food production, various strategies have been envisaged by government and stakeholders at all levels; one of such strategies is hinged on the need to increase farmers access to agricultural finance (credit) to increase productivity, while others focus on agricultural diversity (Osabohien et al, 2018). These strategies are important because, in developing countries, especially in Africa, the agricultural sector accounts for more than $50 \%$ of the entire labour force and it contributes significantly to the Gross Domestic Product (GDP) (Osabohien et al., 2020; Matthew et al., 2019). In the same way, the production of food across the African content, especially in Nigeria, agriculture represents a crucial proportion of activities engaged and captures about $80 \%$ of total industry size with livestock, forestry and fishing accounting for the balance of $20 \%$ (Osabohien et al., 2019). Irrespective of its crucial role, its contribution to GDP has currently dropped as a result of low yields resulting from constrained or limited access to credits by farmers. The sector's contributions to GDP dropped from 31\% (113.64 billion USD to 78 billion USD between 2013 and 2017 (Nevin et al., 2019).

Low food production is one of the major issues that require urgent attention in Africa, with over $50 \%$ of the people depending on subsistence farming, coupled with low production as their sole means of survival (Bachewe et al., 2018). However, it should be mentioned at this stage that African countries differ in terms of mass, demography, and endowment of resources. Therefore, the potential of agriculture to meet the needs of the people varies between countries (Omondi, 2019). Food production is significant, because, shortage in the production of food leads to the deterioration of household's means of livelihood and food security (Omordi, 2019). Duong \& Izumida (2019), in their study noted the importance of agricultural credit and pointed out that credit facilities geared towards the agricultural sector are aimed at increasing agricultural production. They also noted that credit facilities granted to 
farmers has recognised to be the main investment expenditure towards the development of the Nigerian agricultural sector. The reduction of the Nigerian agricultural sector production capacity has which has led to the reduction of foreign exchange earnings can be linked to the deficiency of credit felicity policy and the shortage of data for credit institutions, which could help distribute facilities evenly. Osabohien et al.2018) pointed out that agricultural credit facilities are not only necessitated by the restriction of the ability of self-finance, it also necessitated by the ambiguity relating to the level of farm input materials, production functions and the time spend between inputs and output (Odoemenem and Obinne,2010). This statement is validated in agricultural credit to households' model where the ineffective level of communication existing between the creditors and the debtors was noted, regulation of credit demand thus becomes essential for monetary organisations to affect agricultural credit facilities.

\section{Objective of the Study}

To investigate the Impact of Agriculture on Bank Credit in Nigeria. Agricultural Output is the explained variable as proxy for bank credit; while the explanatory variables are Commercial Bank Loan to the agricultural sector (CBL), and Lending rate (LR), Agricultural credit scheme (ACS) and Total Population (POP). To determine the relationship between Agricultural output and the explanatory variables.

\section{Statement of the Problem}

One of the constraints to agricultural productivity is the inability of farmers to gain access to credit due to the risk and volatility of the sector (Osabohien et al. (2018)). Most importantly, banks and other financial institutions are still reluctant to fund agricultural projects which is evident by stringent credit conditions. As a result, meagre funding sips into the agricultural sector, which accounts for over $70 \%$ of the total labour force of most African economies (FAO, 2011). The contributory and substantial role of the agricultural sector to economic growth and development and particularly, for the realisation of the Sustainable Development Goals by 2030 cannot be understated. Hence, it is imperative to do a review of the agro-food and agro-financing literature, without claiming to be exhaustive. Various studies examined and evident the significant role of farmers' access to finance for the purchase of agricultural machinery and other farm implements to improve agricultural production. From the study of 21,576 dairy farmers in Kenya and using the double-hurdle approach for inferential analysis, Njoku et al. (2018) revealed the positive and significant relationship between farmers' production capacity and access to credit. The study recommends that to boost agro-productivity, there is the need to enhance credit farmers, initiate agricultural insurance and seek alternative collaterals. In a similar study, Osabohien et al. (2018) using the Autoregressive Distribution Lag (ARDL) econometric approach examined how access to credit facilities affect agricultural production and food security in Nigeria, and finds that credit facilities significantly impact on agricultural production and food security in Nigeria.

\section{Literature Review}

\section{Conceptual Issues}

Agriculture sector is a major contributor to GDP of agriculture-based economies as compared to other sectors of the economy and is a primary source of livelihood for more than half of their total workforce (Mondiale, 2008). Credit is needed as an important indirect input among others to enhance productivity in agriculture (Sriram, 2007; Das et al., 2009). With modernization and mechanization of farming systems, farming communities require more farm investment. Since most of the farmers in developing countries are small and marginal with fragmented land holdings, they need credit for such investment. Due to lower rate of savings in these economies, the farmers lack sufficient owned-equity and hence resort to external borrowings (Chisasa \& Makina, 2012).

Most of the farming households are faced with paucity of funds at their end. To fulfil their credit requirements, both institutional and non-institutional of finance are available in a developing economy (Singh et al., 2001). When credit is not available on time and at reasonable rates from institutional (formal) sources, farmers are forced to pay exorbitant rates of interest to non-institutional (informal) lenders (Reddy, 2012; Chaudhuri \& Gupta, 1996). Traditionally when agriculture was mainly subsistence based, informal moneylenders used to cater to credit needs of farmers which were comparatively small. After the Green Revolution across the world which initiated tremendous changes in the cropping pattern, the credit needs of farmers have increased spontaneously; and it was during this period that institutional sources of credit emerged as major players. This was the era when subsistence cropping was replaced by cash cropping. Later on, micro-finance emerged as an effective tool of providing credit to the rural communities (Pradhan, 2013).

Nigeria like many other developing countries faces the challenge of providing adequate food supply for its teeming population. Policies and programmes aimed at boosting agriculture and food industries are being actively promoted. Nigeria needs to take appropriate and pragmatic steps to ensure food industries. An effective national food production policy is needed to provide food to the consumers adequately (Omotayo and Denloye, 2002). The 
Government of Nigeria launched the National Policy of Food Hygiene and Safety in 2000 as an integral goal of this policy is the attainment of high level of food hygiene and safety practices which will promote health, control food-borne diseases, minimize and finally eliminate the risk of diseases related to poor food hygiene and safety of the food produced by the food industries in Nigeria. The policy seeks to stimulate and promote legislations concerning food in areas of production, storage, handling, processing, preservation, trade, transportation and marketing. It also seeks to improve the quality of healthcare through ensuring that all food consumed in Nigeria, whether imported or exported are wholesome, nutritious, free from contaminants and accessible to the consumers at affordable price

According to Udih (2014), bank lending is expected to impact positively on the investible sectors of the economy, through improved agricultural production of goods and services. He opined that sufficient financing of agricultural projects will not only promote food security, but also enhance the entrepreneurship performance of our young investors. Qureshi (2004) contributes that bank credit has the capacity to remove the financial constraints faced by farmers, as it provides incentives to enable famers to switch quickly to new technologies, which can enhance the achievement of rapid productivity and growth. Ijere (2006) viewed bank lending as a catalyst that can activates the engine of growth, enabling it to mobilize its inherent potentials and to advance in the planned or expected direction. However, the Nigerian agricultural sector, which is significantly made up of peasant farmers, relies more on the informal sources of fund for credit supply. These include: Cooperatives, community development association, thrift associations, family, friends andmoney lenders. Nwankwo (2013) asserts that the informal sources cannot meet the credit needs of the farmers adequately. Consequently, in order to enhance credit flow to the sector, the government established The Nigerian Agricultural Cooperative Bank (NACB), now The Nigerian Agricultural Cooperative and Rural Development Bank. There are lot of argument in the literature on commercial bank credit and agri-cultural output. Imoisi et al., (2012) examined credit facilities and agricultural output and productivity in Nigeria from 1970-2010. The results showed that there was a significant relationship between deposit money banks loans and advances and agricultural output. Kolapo, Ayeni and Oke, (2012) carried out an empirical investigation into the quantitative effect of credit risk on the performance of commercial banks in Nigeria over the period of 11 years (2000-2010).

Anyawu et al (2010), one of the objectives of agricultural credit policies over the years was to make adequate credit available to the farmers at the right time and at affordable cost. Various measures have been adopted in pursuance of this objective in the recent past. These include purveyance of credit to the agricultural sector at concessionary interest rate, establishment of agricultural finance institutions, introduction of funding schemes, etc. Despite government efforts to ensure the provision of credit through the various mechanisms embarked upon, credit to the agricultural sector remained low, as it did not result to increased allocation of credit to the agricultural sector during the period before 1999. Economically, active population in agriculture (number) in Nigeria was reported at 12293000 number in 2012, according to the World Bank collection of development indicators, compiled from officially recognized sources. Nigeria - Economically active population in agriculture - actual values, historical data, forecasts and projections were sourced from the World Bank on March of 2021.

Malthusian population theory states that the power of the population is superior to the power of the earth to produce subsistence for it, this means that supplies will run short at a point in time in the near future. Tverbeg (2012) highlighted that the doctrine of the population theory spelt out that the human race will grow on a geometric scale, while food production will remain at the subsistence level or arithmetic level, which will lead to hunger, poverty, squalor, and diseases, unless checked by wars, epidemics, and human vices. Production theory attempts to examine the relationship between resources and how they are transformed into output(s).

\section{Empirical Review}

Obilor (2015) examined the impact of Commercial Banks Credit to agriculture on Agricultural Development in Nigeria; this study underscored the importance of credit availability to the agricultural sector for adequate development pointing out that inadequate capital is a key factor for hampering attainment of food security in Nigeria. Results from the study of Obilor showed that there exists a significant positive relationship between agricultural credit guarantee scheme fund and food production in Nigeria. Also, the recommended that agricultural credit facility in terms of loans and other input supply should be easily accessible to farmers to encourage their participation in the agricultural sector which will increase production. With the application of the Ordinary Least Squares (OLS) techniques analysed the impact of commercial banks credit on agricultural productivity in Nigeria; the study concluded that there is a positive relationship between commercial banks' credit and agricultural productivity. In a similar way (Chris and Ijere, 2006) focused on the significance of commercial banks loan on food availability. The estimated results from this study showed that there exists a positive and significant relationship between agricultural credit scheme and agricultural produce in Nigeria; their findings revealed a 
positive and significant relationship between commercial banks loan to the agricultural sector and food production in Nigeria. The result obtained indicated that an increase in commercial banks credit to agricultural sector will lead to an increase in agricultural production, hence food security in Nigeria. Interest rate which serves as a major factor in determining the desire for credit facilities was also examined. The authors found that a negative relationship exists between interest rate and agricultural output. This establishes that increasing interest rates may deter farmers and agricultural producers from borrowing funds, which may lead to declining output and reduced agricultural investment.

Bidisha et al (2006), attempted to disentangle the relationship between credit, food industries, and agricultural diversity. The study which was carried out through descriptive and econometric analysis focused on Nigeria issues. The study found that access to credit facility tends to improve food companies and allows households to achieve greater dietary diversity. Umoru (2016) accessed how changes in the level of deposits in community banks influence total agricultural sales and direct-to-consumer agricultural sales of local food between 2002 and 2012 , in the states which include Northern part of the country, Southern and other part of the country. The study finds that changes in community bank deposits had a positive impact on changes in direct-to-consumer agricultural sales of local foods. Also, total agricultural sales may not be impacted by changes in community bank deposits and that the consolidation of the commercial banking sector may influence the viability of farms in accessing credit.

\section{Methodology \\ Data Source}

The data for this research work is obtained from secondary sources, particularly from the 2019 Central Bank of Nigeria bulletin (CBN.) . Time series data covered a period of 25 years (from 1998 to 2018) and was used to estimate the specified model below. The method of analysis applied in this research involved econometric techniques. The econometric analysis applied an econometric model that was fitted into data using the approach of the Autoregressive Distributed Lag (ARDL) Bounce testing procedure developed by Pesaran et al. to examine long-run relationship amongst population, agricultural productivity, and food industry as well as short-run dynamics. The bound test was adopted for four reason reasons stated thus; firstly, it does not require that the variables under study must be integrated of the same other, unlike the Johansen Cointegration approach. Secondly, the bound test is suitable for small or infinite sample data, unlike the conventional approach which requires a large sample size. Thirdly, it allows the cointegration relationship to be estimated using the Ordinary Least Square method, and lastly, the long and short run parameters of the model can be estimated simultaneously as used in the work of Momoh and Jimah (2021).

\section{Model Specification}

To investigate the Impact of Agriculture on Bank Credit in Nigeria, Agricultural Output is the explained variable as proxy for food industry; while the explanatory variables are Commercial Bank Loan to the agricultural sector (CBL), Agricultural Credit Scheme and Lending Interest rate (LR) and Total Population (POP) as shown below.

$\mathrm{AGOt}=\mathrm{f}(\mathrm{POPt}, \mathrm{ACSt}, \mathrm{CBLt}, \mathrm{LRt})$

Where:

AGO represent Agriculture Output, measured by the depth of food deficit in Nigeria; POP is the total population in Nigeria, ACS represents Agricultural credit scheme, CBL represents Commercial bank loans, etc made available to the agricultural sector, LR represents the lending interest rate and $t$ is time.

The model can be represented in an explicit form as

$\mathrm{AGOt}=\beta 0+\beta 1 \mathrm{POPt}+\beta 2 \mathrm{ACSt}+\beta 3 \mathrm{CBLt}+\beta 4 \mathrm{LRt}+\mu \mathrm{t}$

Where;

$\beta 0$ is the Intercept, $\beta 1, \beta 2, \beta 3$ and $\beta 4$ are the coefficients of total population, agricultural credit scheme, commercial bank loan, and lending interest rate and $\mu$ as the error term respectively.

Thus, the expected signs of the coefficient of the explanatory variables are, $\beta 0>0, \beta 1<0, \beta 2>0, \beta 3>0$ and $\beta 4$ $<0$. Hence, increase in the explanatory variables encourages more food industries.

\section{Method of Estimation}

The model for this study is hinged on bank credit channel theory. It explains who poses interest on agriculture through banks capital, especially when banks' lending is constrained by a capital adequacy requirement. Thus, an increase in interest rates will raise the cost of banks' external funding, but reduce banks' profits and capital. The tendency is for the banks to reduce their supply of loans if the capital constraint becomes binding. However, banks could also become more willing to lend during certain periods because of an improvement in their underlying financial condition. 
To estimate the above formulated model, time series data from 1998 to 2018 would be made available for the variables. The economic view package (E-views, version 10$)$ would be used in the estimation process. The ARDL model for equation (3) is specified as:

$\Delta \mathrm{AGOt}=\delta 0+\sum \mathrm{Pi}=0 \delta 1 \Delta \mathrm{POPt}-1+\sum \mathrm{p} \mathrm{i}=0 \delta 2 \Delta \mathrm{ACS} \mathrm{t}-1+\sum \mathrm{p} \mathrm{i}=0 \delta 3 \Delta \mathrm{CBLt}-1+\sum \mathrm{pi}=0 \delta 4 \Delta \mathrm{LR} \mathrm{t}-1+\mu \mathrm{t}$

Once Cointegration is established. The long-run relationship is established using the conditional ARDL model specified as;

$\mathrm{AGO}=\delta 0+\beta 1$ POPt $-1+\beta 2 \mathrm{CBLt}-1+\beta 3 \mathrm{ACSt}-1+\beta 4 \mathrm{LRt}-1+\mu \mathrm{t}$.

\section{Analysis of Results}

The techniques of analysis or investigation is least square estimation technique. The reason being that the models are identified. Secondly, we derived the historical simulation from the dynamic series to see how the macroeconometric models track the actual series. This is important for counter-factual analysis and to see if the models effectively evaluate the structure of agricultural output in the economy.

\section{Unit Root Test for Stationarity}

The stationary test was conducted from time series data using the Augmented Dickey-Fuller to determine the level of the unit root. Although, the bounds testing procedure does not require the pre-testing of the variables included in the model for unit roots owing to its suitability irrespective of whether the regressors in the model are purely integrated of 0 ; ie, $\mathrm{I}(0)$, purely order $1[\mathrm{I}(1)]$ or mutually cointegrated. The application of unit root tests in the ARDL procedure might still be necessary in order to ensure that the variables are integrated of order one and none of the variables is integrated of order 2 or beyond because the computed F-statistics are valid for only variables that are I(0) or I(1). The Augmented Dickey-Fuller (ADF) test was used to investigate whether the variables used in this study have a unit root or not.

Table: 1 Estimate From the Unit Root Test Stationarity

\begin{tabular}{|l|l|l|l|l|l|l|}
\hline Variable & $\begin{array}{c}\text { ADF Test } \\
\text { Level }\end{array}$ & $\begin{array}{c}\text { ADF Test } \\
\text { ast level }\end{array}$ & \multicolumn{3}{|c|}{ Mackinnon Critical Value } & $\begin{array}{c}\text { Order of } \\
\text { integrate }\end{array}$ \\
\hline AGO & -2.430 & -4.152 & -3.824 & -2.986 & -2.632 & $1(1)$ \\
\hline POP & -0.574 & -3.529 & -4.350 & -3.632 & -3.254 & $1(1)$ \\
\hline ACS & -3.928 & -1.252 & -4.500 & -3.658 & -3.268 & $1(0)$ \\
\hline CBL & 2.549 & -5.648 & -3.710 & -2.986 & -2.632 & $1(1)$ \\
\hline LR & -3.731 & -6.376 & -4.350 & -3.632 & -3.254 & $1(0)$ \\
\hline
\end{tabular}

Source: Researcher via E-view software

The Augmented Dickey-Fuller (ADF) unit root testing of the variables indicates that three of the variables which include AGO for the agricultural output, POP for the total population, and CBL (Commercial bank loans) attain their stationarity at the first difference which means that they are all integrated of order one while ACS (Agricultural credit scheme) and LR (lending rate) attain stationarity at level which means it was integrated of order zero. From the result above, the variables are not integrated at the same order, therefore, we conduct the Autoregressive Distributed Lag (ARDL) Bounce test.

\section{ARDL Bounce Test for Cointegration}

Cointegration test is employed to ascertain the long-run equilibrium relationship between Commercial bank loan and agricultural output. The table 2 below presents the ARDL bounds test results. Evidence from Table 2 shows that the F-statistic goes beyond the critical value of the upper bound at 5\% significance level, showing a cointegration amongst commercial bank loan and agricultural output. Meaning, there exist a long run relationship between commercial bank loan and agricultural output. 
Table 2 ARDL Bounce Test

\begin{tabular}{|l|l|l|}
\hline Test Statistics & Value & K \\
\hline F - Statistics & 5.87638 & 4 \\
\hline
\end{tabular}

Critical Value Bounds

\begin{tabular}{|l|l|l|}
\hline Significant & $1(0)$ & $1(1)$ \\
\hline $10 \%$ & 2.45 & 3.52 \\
\hline $5 \%$ & 2.86 & 4.01 \\
\hline $2.5 \%$ & 3.25 & 4.49 \\
\hline $1 \%$ & 3.74 & 5.06 \\
\hline
\end{tabular}

Source: Researcher Via E-view Software

The table below depicts the ARDL model selection using the Hannan-Quinn Criteria. The study employs the Hannan-Quinn Criteria to select the optimal model [ARDL $(4,0,1,0,1)$ ] to estimate the long-run and the short-run equilibrium relationship between the variables. Using the optimal model [ARDL $(4,0,1,0,1)$ ], the normalized cointegration equation for the ARDL regression analysis is expressed as:

Cointeq ECM = AGO-(-0.000021*POP +0.000022*ACS+0.071304*CBL+2.554902*LR-88.7060)

Table 3: Short run Relationship Estimation

\begin{tabular}{|l|l|l|l|l|}
\hline Variable & Coefficient. & Std. Error & T-statistic & Prob. \\
\hline D (POP) & -0.0000 & 0.0000 & -2.1377 & 0.0538 \\
\hline D (ACS) & -0.0000 & 0.0000 & -0.4628 & 0.6518 \\
\hline D (CBL) & -0.0146 & 0.0055 & 2.6467 & 0.0213 \\
\hline D (LR) & -0.0476 & 0.1299 & 0.3637 & 0.7205 \\
\hline ECM-1 & -0.1803 & 0.0511 & -3.5256 & 0.0042 \\
\hline
\end{tabular}

Source: Researcher Via E-view Software

The result of the estimated coefficients of the long run relationship indicates that Population has a negative influence on Agricultural output in Nigeria. The estimated coefficient of the population

$(-0.000021)$ implies that 1 unit increase in population will decrease Agricultural output by approximately 0.000021 unit all things being equal. Agricultural credit scheme was found to be positively related to Agricultural output with an estimated coefficient of 0.000022. This implies that a 1 unit increase in Agricultural credit scheme will lead to an increase in Agricultural output by a magnitude of 0.000022 units. Commercial bank loan was found to be positively related to Agricultural output with an estimated coefficient of (0.071304) which implies that 1 unit increase in commercial bank loan will lead to an increase in Agricultural output by 0.071304 units. The lending rate was found to be positively related to Agricultural output with an estimated coefficient of (2.554902) which implies that 1 unit increase in Gross fixed capital formation will lead to an increase in Agricultural output by 2.554902 unit. All variables were statistically significant at their respective level of significance. All variables apart from Lending Interest rate meet the a priori expectation.

The results of this study closely followed the area that improved level of credit given to farmers to enhance the productivity level of the agricultural sector and thus lead to an increase in the level of Agricultural products in Nigeria as seen in ARDL result. It was noted that there exists a significant positive relationship between Agricultural product and food industries. This study explained that one percent increase in the availability of agricultural credit to farmers amounted to a $2.5 \%$ and increase in agricultural productivity in Nigeria, this of course, follows the apriori expectations.

\section{Diagnostic Test and Stability Test}

The ARDL model was validated and verified using a series of diagnostic and stability check to scrutinize the independence of the residuals from the fitted model. For a robust ARDL model, the residuals must exhibit the required independence during the diagnostic and stability checks, if not, the model is unacceptable statistically and requires further model modification before additional diagnostic and stability checks. 
In this way, the ARDL model becomes unbiased and robust to make the correct statistical inferences. Diagnostic tests employed to validate the ARDL model include; Heteroskedasticity Test, Jarque-Bera Test and Ramsey RESET Test as presented below.

ARDL residual heteroskedasticity was tested with Breusch-Pagan-Godfrey Test statistic. The result showed that the Probability value of the observed R-squared is greater than $5 \%$ this means we accept the null hypothesis which indicates no heteroskedasticity.

Table 4: Diagnostic Test Results

\begin{tabular}{|l|l|l|l|}
\hline F-statistic & 0.806918 & Prob F (19,10) & 0.6279 \\
\hline Obs R-squared & 9.247573 & Prob. Chi-Square & 0.5088 \\
\hline Scaled explained SS & 1.973829 & Prob. Chi-Square & \\
\hline
\end{tabular}

\begin{tabular}{|l|l|l|l|}
\hline \multicolumn{3}{|c|}{ JARQUE-BERA TEST } \\
\hline Jarque - Bera & 0.242205 & Probability & 0.885943 \\
& & & \\
\hline
\end{tabular}

\begin{tabular}{|c|c|c|c|}
\hline \multicolumn{4}{|c|}{ RAMSEY RESET TEST } \\
\hline F - statistic & Value & DF & P - Value \\
& 0.116174 & $(1,11)$ & 0.7396 \\
\hline
\end{tabular}

ARDL residual normal distribution was tested with Jarque-Bera test statistic. Evidence from table 4 shows that the null hypothesis of multivariate normal distribution was accepted at the $5 \%$ significance level, this means that; the ARDL residuals are normally distributed. ARDL functional mis-specification was estimated with Ramsey RESET Test statistic. Findings showed that the probability level is greater than 5\%, therefore, we accept the null hypothesis, meaning that, the ARDL model is in its functional form.

\section{Conclusion}

We investigated the impact of agriculture on food industry in Nigeria. Measures aimed at increasing agricultural output were discussed and the correlations between agricultural produce and food industry were highlighted. Functional model was formulated based on theory and operational form of the model was formulated for estimation. From the estimated model, Agricultural credit scheme, Lending rate, Population and Commercial bank loan were all important in affecting aggregate agricultural output in Nigeria. Results of the historical simulation indicated that the macro-econometric models provide an adequate and accurate representation of the Nigeria economy. The results suggest that, as in most developing countries, Agricultural credit scheme is an effective instrument for counter-cyclical agricultural output. Results of the policy simulation were satisfactory. Consequently, the macro-econometric model in this study contribute to the development of policy and programming by shedding light on the choice to be made and indicating the magnitude and direction of responses that can be expected from changes in key agricultural policy. Despite difficulty in modelling in a developing countries economy, results obtained from this study are sufficiently useful not only for pedagogic purposes but also for macroeconomic policy analysis.

Generally, in developing countries, lack of access to credit pose a limitation on small holders' investment (food industry) and on agricultural production as well as income creation for farmers in particular and the government in general. Microcredit in Nigeria is unarguably seen as an effective strategy with the potential of improving agricultural output and food indusry in the country. In order to achieve this objective in Nigeria, the opportunities of accessing credit facilities to farmers need to be increased and the volume also should be expanded. To this, strategy will contribute immensely in reducing constraints to capital and improve the level of agriculture and food 
industry. Furthermore, placing the Sustainable Development Goal 2; which aims at eliminating hunger and achieve sustainable agricultural output globally by year 2030 .

\section{References}

Abayomi F, (2006). An overview of Nigerian agricultural sectors. Journal of Agricultural Economics, 8(3): 7-16. Central Bank of Nigeria, 2007. Annual report and statement of account.

Child M.N. (2008). The effect of a depressed economy on agricultural sector. Journal of African Studies 3 (2): 152-167.

Emona A.I. (2001). Long-run agricultural growth in Nigeria: An empirical analysis. Journal of Policy Issues 3 (7): $12-20$.

Hamilton, J.D. (1983). Oil and the macroeconomy since World War II. Journal of Political Economy, 91(2):228248.

Longe J.B. (2008). Economics of agricultural production in Nigeria. Journal of Policy Issues, 1(2): 2-10.

Malthus T.R. (2012). An essay on the principle of population as it affects the future improvement of Society.

Obadan M.I, 1990. Agricultural development strategies and performance in Nigeria: from OFN to OFFRI IRORO. Journal of Arts and Social Sciences, 3 (1 \& 2): 3-11.

Osabohien R, Osabohien E, Urhie E. (2018). Food security, institutional framework and technology: Examining the nexus in Nigeria using ARDL approach. Curr Nutr Food Sci 2018; 14(2): 154-63

Osabohien R, Osuagwu E. (2017). Social protection policies and agricultural output in Nigeria: Empirical investigation using household survey data. 4th Covenant University International Conference on EGovernance in Nigeria (CUCEN) May 7-9, 2017;

Petrick M. (2004). Credit rationing of Polish farm households: A theoretical and empirical analysis (No 26) 2004. Uniamikogbo S.O. and Enoma A.I, (2001). The Impact of monetary policy on manufacturing sector in Nigeria: An Empirical Analysis. The Nigerian Journal of Economic and Financial Review, 3 (2): 37-45.

Uniamikogbo SO, Ewanehi SE, (1998). Agricultural sector's performance in a deregulation economy: the case of Nigeria. The Nigerian Journal of Economic and Management Studies, 3 (2): 1-8

Simtowe F, Zeller M, Phiri A. (2006). Determinants of moral hazard in microfinance: Empirical evidence from joint liability lending programs in malawi. Afr Rev money finance bank 2006; 5-38. 